\title{
Assessing Fiscal Sustainability in Ukraine: TVP and VAR/VEC Approaches
}

\author{
Victor Shevchuk, Roman Kopych
}

\begin{abstract}
A B S T R A C T
Objective: The purpose of this article is to investigate fiscal sustainability in Ukraine, using quarterly data sample for the period between 2000 and 2016, in accordance with a recursive algorithm derived from the law of motion of the debt-to-GDP ratio developed by Croce and Juan-Ramon (2003).
\end{abstract}

Research Design \& Methods: An assessment of fiscal sustainability in Ukraine is provided according to a recursive algorithm derived from the law of motion of the debtto-GDP ratio, developed by Croce and Juan-Ramon (2003). Both time-varying parameters (TVP) and vector error-correction autoregression (VAR/VEC) models are used.

Findings: It is found that there is causality running from the budget surplus to the gap between real interest rate and GDP growth rate, however it is not sufficient to guarantee a sustainable debt to GDP ratio.

Implications \& Recommendations: Our findings argue in favour of fiscal policy actions aimed at an increase in the government revenues, combined with the public sector expenditure cuts, as current policies do not seem to be sufficient to achieve fiscal sustainability. A more detailed study is needed in order to identify most efficient approaches for a decrease in the budget deficit across a detailed 'menu' of expenditure and revenues. Any attempts to decrease interest rate and/or stimulate output growth by an expansionary monetary stance are likely to be counterproductive in the presence of substantial public external debt.

Contribution \& Value Added: This empirical study provides an indication of the possibility of default on foreign public debt liabilities in Ukraine.

\begin{tabular}{llll}
\hline Article type: & research paper \\
& fiscal sustainability; budget surplus; real interest rate; Kalman filter; \\
Keywords: & VAR/VEC; Ukraine & & \\
JEL codes: & E17, E62, F34 & & \\
\hline Received: 30 & November 2017 & Revised: 30 May 2018 & Accepted: 30 May 2018 \\
\hline
\end{tabular}

\section{Suggested citation:}

Shevchuk, V., \& Kopych, R. (2018). Assessing the Fiscal Sustainability in Ukraine: TVP and VAR/VEC approaches. Entrepreneurial Business and Economics Review, 6(3), 73-87. https://doi.org/10.15678/EBER.2018.060305 


\section{INTRODUCTION}

Recent worsening of the budget balance and the build-up of public debt in Ukraine raises concerns about the sustainability of current fiscal policies marked by a simultaneous increase in both government revenues and expenditures (Figure 1). The primary budget balance was in surplus since mid-2000, in sharp contrast to the profligate fiscal policies of 1990s, but there was a reversal in the fiscal policy stance in the wake of the world financial crisis of 2008-2009. Public external debt was on a steady decline since the beginning of the previous decade, but a steep rise in the government foreign liabilities was followed by two financial crises of 2008-2009 and 2014-2015, as the main way of deficit financing, with a likely relation to the exchange rate developments. As indicated by trends of fiscal variables, steady worsening of the fiscal stance since 2005 lasted until 2013, mainly due to an accelerated increase in the government expenditure. A number of factors contributed to this outcome, such as the growing state support for economic activities, expansion of higher education or modernisation of transport infrastructure, but the most important factor was a significant increase in social transfers. As the latter episode of raising public external debt occurred against the backdrop of a military conflict with neighbouring Russia, there has been a significant increase in expenditure on defence.

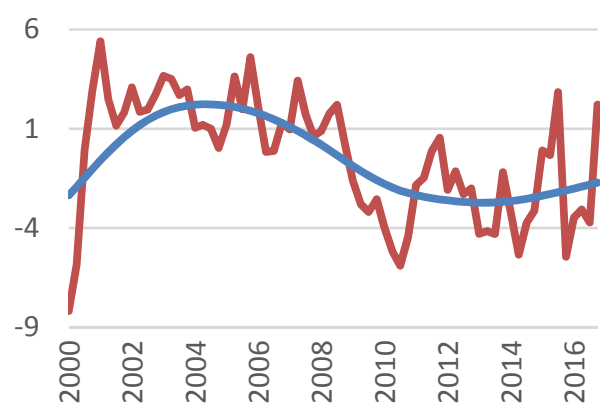

a) primary budget balance (\% of GDP)

40

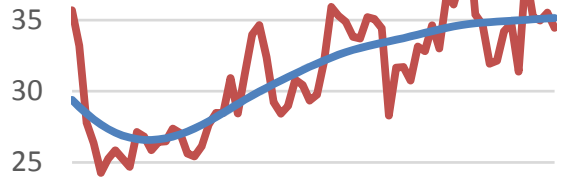

20

c) government expenditure (\% of GDP)

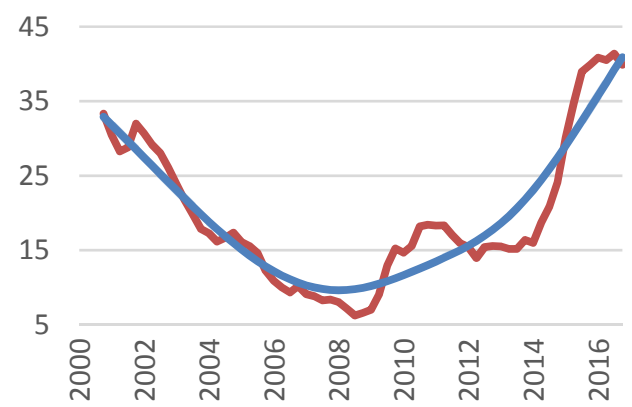

b) public external debt (USD bn)

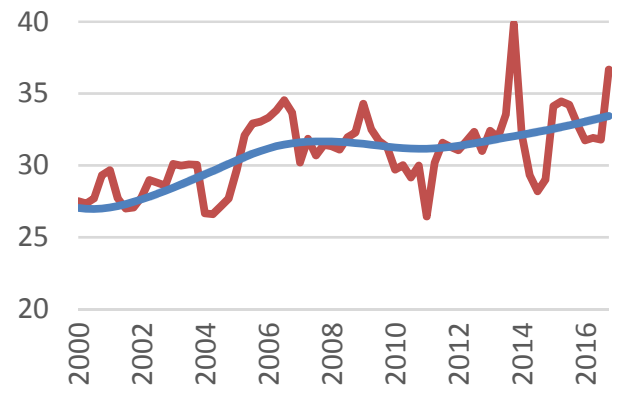

d) government revenue ( $\%$ of GDP)

Figure 1. Ukraine: selected fiscal policy indicators, 2000-2016

Note: the trends of all fiscal variables are obtained with the Hodrick-Prescott filter. Source: the Ukraine's Ministry of Finance online database. 
The purpose of this article is to investigate fiscal sustainability in Ukraine using quarterly data sample between 2000 and 2016, in accordance with a recursive algorithm derived from the law of motion of the debt-to-GDP ratio developed by Croce and Juan-Ramon (2003). It is hypothesised that fiscal policy has a potential to affect the level of interest rate, thus laying foundations for sustainability of public debt, which is perceived as an ability to meet long-term public sector liabilities with unchanged monetary policies. To the best of our knowledge, this is the first empirical study of fiscal sustainability in Ukraine using one of the well-known fiscal response functions.

The remaining part of this article is organised as follows: section 2 provides a brief review of fiscal sustainability issues. Section 3 presents data and preliminary test results. Section 4 discusses the main results of the empirical testing of the relationship between budget surplus and GDP-adjusted real interest rate. Conclusions are presented in section 5.

\section{FISCAL SUSTAINABILITY: THEORY AND EMPIRICAL STUDIES}

Fiscal sustainability means that public debt does not exceed present value of expected future primary budget surpluses (Besancenot, Huynh, \& Vranceanu, 2004; Bravo \& Silvestre, 2002), being dependent upon the actual values of real interest rate, exchange rate, output growth, etc. ${ }^{1}$. Fiscal sustainability is about guarantees of fiscal solvency in the future and implies an ability to meet long-term public sector liabilities (Giammarioli, Nickel, Rother, \& Vidal, 2006). Intertemporal fiscal sustainability used to be associated with the lack of public debt bubble, when the value of government liabilities is growing faster, compared to the debt service capacity (Mihaljek, 2005; Mendoza \& Ostry, 2008). Sustainability requires achieving solvency with unchanged policies (Croce \& Juan-Ramon, 2003).

It is common to assess fiscal sustainability with stationarity and cointegration tests (Afonso, 2005). As the initial value of public debt should be equal to the present value of future budget surpluses, the present value of future public debt should be equal to zero. Thus, fiscal sustainability implies stationarity of budget balance or public debt. For empirical verification of this fact, the Augmented Dickey-Fuller (ADF), the Phillips-Perron (PP) or Kwiatkowski-Perron-Schmidt-Shin (KPSS) tests are frequently used. However, the unit root methodology is criticised on the grounds of the measurement bias towards positive results (Herzog \& Dausch, 2015). For example, it is found that both ADF and PP tests result in overoptimistic evidence of public debt sustainability for such countries as Cyprus or Portugal, which were not good examples of debt management in past decades. On the contrary, in a study of $11 \mathrm{EU}$ countries, only 2 out of 22 time series for the budget balance and the public debt are stationary, brought in favour of fiscal sustainability and they do not envisage any fiscal problems (Bajo-Rubio, Diaz-Roldán, \& Esteve, 2009). Another issue is that fiscal sustainability tests are based on the past developments of public debt and budget deficit. The test outcome could be dominated by an influential, but anomalous period in distant past, which is not relevant to the current fiscal policy stance.

In a wider context, a sustainable fiscal policy must satisfy the standard solvency condition according to which the initial stock of public debt should be equal to the present

\footnotetext{
${ }^{1}$ See Chalk and Hemming (2000), Hemming and Petrie (2000) or Tanner (2003) for a detailed survey of fiscal sustainability issues.
} 
value of future primary budget surpluses. In the most general form, fiscal sustainability implies maintaining the inter-temporal budget constraint:

$$
\int_{0}^{\infty}(G-T)_{t} e^{-r t} d t=B_{0}
$$

where:

$B_{0}$ - the initial level of public debt,

$r$ - the real interest rate,

$G$ - government expenditure,

$T$ - government revenue.

If $\lim _{t \rightarrow \infty} B_{t} e^{-r t}=0$, i.e. discounted present value of public debt is zero, then current public debt should be equal to future budget surpluses. If we assume that

$$
\int_{0}^{\infty}\left(T^{*}-G\right)_{t} e^{(y-r) t} d t=\frac{B_{0}}{Y_{0}}
$$

then

$$
T^{*}-G=\frac{B_{0}}{Y_{0}}(r-y)
$$

where:

$y$ - the output growth rate,

$T^{*}$ - the equilibrium value of government revenues.

It is clear from the equation (2b) that an increase in the interest rate or a slowdown in the output growth requires higher budget revenues in order to achieve fiscal sustainability.

Despite the popularity of stationarity and cointegration tests to assess if deficits are sustainable, there are numerous arguments that such tests are incapable of rejecting sustainability (Bohn, 2007). It is suggested that error-correction-type policy reaction functions are better tools for understanding deficit problems. One of the approaches implies testing the reaction of budget balance to public debt, and another one refers to the relationship between the budget balance and interest rate.

Croce and Juan-Ramon (2003) proposed a recursive algorithm based upon the law of motion of the debt to GDP ratio to analyse the sustainability of fiscal policy as follows:

$$
\begin{gathered}
b_{t}=\beta_{t} b_{t-1}-g_{t} \\
g^{*}=\left(\beta^{*}-1\right) b^{*} \\
g_{t}=g^{*}+\lambda_{t}\left(b_{t-1}-b^{*}\right)
\end{gathered}
$$

where:

$b_{t}$ - the stock of public debt (\% of GDP);

$g_{t}$ - the primary budget surplus (\% of GDP);

$g^{*}$ - the equilibrium primary budget surplus (\% of GDP);

$\beta^{*}$ - the discount coefficient that allows for the convergence to steady-state level of public debt $b^{*}$.

Equation (3) shows that the share of public debt in GDP (domestic and foreign) is increased by the primary deficit and the interest payment on lagged public debt. As coefficient $\beta_{t}$ measures the relationship between interest rate and output growth, $\beta_{t}=$ $\left(1+r_{t}\right) /\left(1+y_{t}\right)$, where $r_{t}$ is the real interest rate and $y_{t}$ is the GDP growth rate, an increase in the cost of borrowing or a slowdown in output contribute to a public debt build-up, along with persistent budget deficits. 
Target variables are defined in Equation (4), which refers to both fiscal variables and discount factor that would prevail in the steady-state. Equation (5) characterises the government reaction function. The primary fiscal surplus is divided into (1) primary surplus ratio $g^{*}$ associated with the steady-state and (2) the policy response to the public debt gap $\lambda_{t}\left(b_{t-1}-b^{*}\right)$.

After necessary substitutions we obtain

$$
b_{t}=\left(\beta_{t}-\lambda_{t}\right) b_{t-1}-\left(\beta^{*}-\lambda_{t}-1\right) b^{*}
$$

Consequently, it is proposed to use $\beta_{t}-\lambda_{t}$ as the indicator of sustainability, with

$$
\beta_{t}-\lambda_{t}=\left[\frac{1+r_{t}}{1+y_{t}}-\frac{g_{t}-g^{*}}{b_{t-1}-b^{*}}\right]
$$

Values of $\beta_{t}-\lambda_{t}$ below 1 indicate a sustainable position, while values consistently above or equal to 1 signal unsustainability. It is assumed that the debt-to-GDP ratio would converge to its long-term target only if $\left(\beta_{t}-\lambda_{t}\right)<1$. In practical terms, the value of $\beta_{t}$ is determined by the difference between real interest rate and GDP growth rate, $r_{t}-y_{t}$. It is assumed that $\beta_{t} \approx 1$ for stable industrial economies, $\beta_{t}>1$ for economies with capital scarcity, and $\beta_{t} \gg 1$ for unstable economies (with risk of default). The parameter $\lambda_{t}$ measures a ratio between (1) the deviation of the observed primary budget surplus ratio with respect to the primary budget balance that stabilises the public debt dynamics and (2) the deviation of the actual public debt ratio with respect to the target debt ratio, indicating the intensity of the policy response at time $t$, given the debt-ratio gap in the previous period. Empirical testing of fiscal sustainability implies identification of the causality $\lambda \Rightarrow \beta$, which is considered as a sign of public debt convergence towards its steady-state. In fact, the algorithm is about whether an improvement in the primary budget balance (higher $\lambda_{t}$ ) contributes to a decrease in the spread between real interest rate and GDP growth rate (lower $\beta$ ).

Empirical investigations concerning fiscal sustainability used to be conducted in a testing framework based on stationary or co-integration properties of fiscal variables (Afonso, 2005), even though they were subjected to numerous criticisms such as restrictive assumptions on the real discounting rate, a bias in unit-root tests due to ignorance of cyclical components of primary surplus (like output gap or government cyclical spending), time series structural breaks or existence of an upper bound on the primary budget balance (or the public debt-to-GDP ratio) requiring additional economic considerations, such as the existence of distortionary taxation (Aldama \& Creel, 2016). Another approach implies calculation of synthetic indicators of fiscal sustainability, for example Rudin and Smith (1994), Blanchard (2000), Talvi and Vegh (2000). Indicators of fiscal sustainability S1 and S2 are calculated up to 2050 for the European countries (EU Sustainability, 2010), accounting for the long-term effects of ageing costs and assumptions concerning the level of deficit-debt adjustments and the interest rate on public debt. Several proposals are based on the construction of fiscal response functions which test the backward-looking relationship between the primary budget surplus and (1) the initial public debt ratio (Bohn, 1995; Mendoza \& Ostry, 2008) or (2) the gap between the real interest rate and GDP growth rate (Croce \& Juan-Ramon, 2003) in econometric way. It is quite popular to test fiscal reaction functions between government revenue and expenditure, for example Ciżkowicz, Rzońca and Trzeciakowski (2015) for 12 euro area member states.

Empirical studies for the CEE countries utilise various approaches for testing fiscal sustainability. Based on the analysis of the gap between real interest rate and GDP growth rate, 
it is established that Hungary's government debt left the sustainable path in 2001/2002 (Tóth, 2012). Several indicators of fiscal sustainability are used for the analysis of Croatia (Mihaljek, 2005), the Czech Republic (Krejdl, 2006), Slovenia (Genorio, 2005) and Poland (Green, Holmes, \& Kowalski, 2001). On the eve of the world financial crisis of 2008-2009, it was found that fiscal sustainability seemed to be a problem in the Czech Republic, Hungary, Poland, as well as in Albania and Croatia (Aristovnik \& Bercic, 2007). More recently, it is found that fiscal policy in Poland is 'weakly sustainable', as there is bi-directional causality between expenditure and revenues (Tronzano, 2017). On the whole, it is suggested that sustainability of public debt stock in the CEE countries has improved (Wysocki, 2017), but only in a weak sense' (Krajewski, Mackiewicz, \& Szymańska, 2016). However, it is established that that current public debt ratio as of 2015 for Bulgaria and Romania is not sustainable (Bökemeier \& Stoian, 2016). Among other countries, the recursive algorithm of Croce and Juan-Ramon (2003) is used for empirical assessment of fiscal sustainability for several Latin American countries (Cruz Rodriguez, 2014; Paunovic, 2005).

\section{DATA AND STATISTICAL TESTS}

Quarterly data on the primary budget balance, $g_{t}$ (\% of GDP) between 2000 and 2016 are taken from the Ukraine's Ministry of Finance online database. The budget balance is seasonally adjusted by means of the Census X-11 method. We build time series for the gap between real interest rate and GDP growth rate, $r_{t}-y_{t}(\%)$, by using data from the IMF International Financial Statistics online database. The lending rate of commercial banks is used as an indicator of a nominal interest rate.

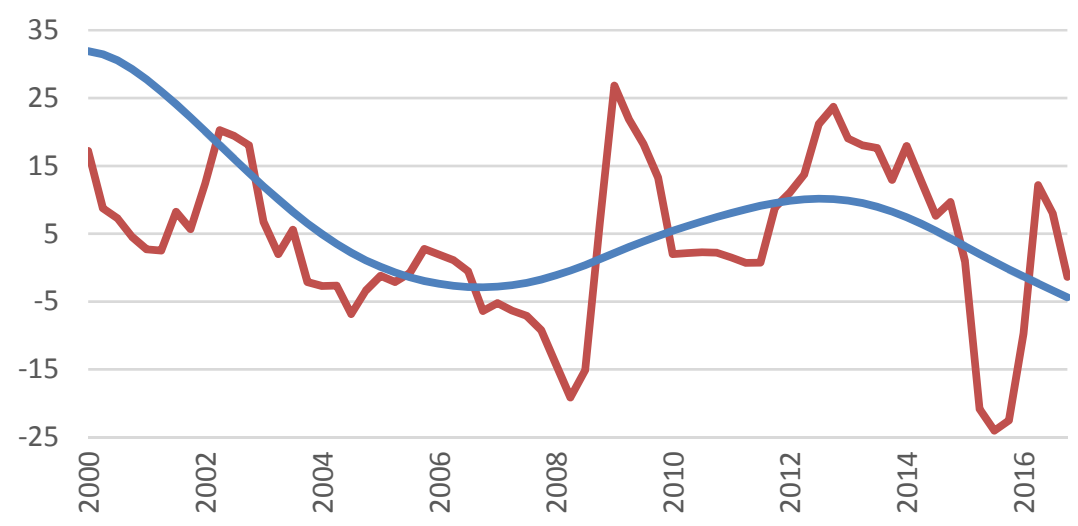

Figure 2. Ukraine: actual and equilibrium trend values of the gap between real interest rate and GDP growth rate $\left(r_{t}-y_{t}\right), 2000-2016$

Note: trend values are obtained by the Hodrick-Prescott filter, using a longer sample of 1997Q1 to 2016 Q4.

Source: personal calculations based upon the IMF International Financial Statistics data.

As it is seen in Figure 2, equilibrium value of $r_{t}-y_{t}$ increased to as high as $30 \%$ in the wake of the 1998-1999 financial crisis, but it gradually decreased to negative values in the period of 2005-2007. Actual values of $r_{t}-y_{t}$ had low records in 2007-2008, on the eve of the world financial crisis of 2008-2009, with an overshooting above trend in 2009. Another peak of the gap between real interest rate and GDP growth rate is observed in 2012, when the National 
Bank of Ukraine lost 7.2 bn USD (or 23\%) of its international reserves due to a strong demand for foreign currency by residents, followed by a gradual decline in this indicator over the next two years and a sharp drop in 2015, due to an outburst of inflation that was not confronted with a proportional increase in the nominal interest rate. As of 2016, both actual and trend values of $r_{t}-y_{t}$ seem to be stabilised at rather comfortable level around zero.

As a preliminary testing exercise, results of the Ganger test for two-way causality between $g_{t}$ and $r_{t}-y_{t}$ that proxies the $\lambda \Rightarrow \beta$ causality are presented in Table 1 for the 2000Q1-2016Q4 sample and two sub-samples ${ }^{2}$. The choice of sub-samples is motivated by the timing of the two financial crises in 2008-2009 and 2014-2015, and aims at detecting possible changes in the relationship between $g_{t}$ and $r_{t}-y_{t}$. It is clear that the budget balance has an impact on the GDP-adjusted real interest rate only for the 2000Q1-2008Q4 sub-sample. There is no reverse causality between both variables, either.

Table 1. Granger causality test

\begin{tabular}{|c|c|c|c|}
\hline \multirow{2}{*}{ Sample } & \multirow{2}{*}{ Lags } & \multicolumn{2}{|c|}{ Source } \\
\cline { 3 - 4 } & & $\boldsymbol{g}_{\boldsymbol{t}}$ does not cause $\boldsymbol{r}_{\boldsymbol{t}}-\boldsymbol{y}_{\boldsymbol{t}}$ & $\boldsymbol{r}_{\boldsymbol{t}}-\boldsymbol{y}_{\boldsymbol{t}}$ does not cause $\boldsymbol{g}_{\boldsymbol{t}}$ \\
\hline 2000Q1-2008Q4 & 1 & $3.053\left(0.09^{*}\right)$ & $0.041(0.83)$ \\
\hline 2000Q1-2012Q4 & 1 & $1.269(0.28)$ & $0.843(0.36)$ \\
\hline 2000Q1-2016Q4 & 4 & $0.407(0.80)$ & $1.575(0.19)$ \\
\hline
\end{tabular}

Source: own elaboration.

However, the Johansen test indicates that there is a long-run relationship between the budget balance and the GDP-adjusted real interest rate in a four variable framework including a nominal exchange rate (local currency per U.S. dollar), $e_{t}$, and the current account balance (\% of GDP), $c a_{t}$ (Table 2$)^{3}$. Accounting for both exchange rate and current account balance is justified on the grounds of heavy reliance of Ukraine's budget revenues upon the exports of metals and agricultural commodities as well as because of close links of government expenses to the prices of imported natural gas and crude oil. As indicated by the Akaike and Schwartz information criteria, two lags are included in the short-run component of the model. Both trace and eigenvalue tests indicate the presence of two co-integrating equations (the results do not differ substantially if the model is run with three and four lags). The same result does hold for the sub-samples of 2000-2008 and 2000-2012.

\footnotetext{
${ }^{2}$ Although the original algorithm by Croce and Juan-Ramon (2003) is based upon the assessment of target values of the debt and primary surplus ratios, in practice it is quite difficult to find proper values of both $b^{*}$ and $g^{*}$, especially for the economy with significant structural instability, as it is the case for Ukraine. Under such circumstances, identification of causality between $g_{t}$ and $r_{t}-y_{t}$ could be considered as a reliable alternative to calculation of the value of $\beta_{t}-\lambda_{t}$, being in line with the logic of proposed fiscal sustainability algorithm which is about whether an improvement in the primary budget balance brings about a decrease in the spread between real interest rate and GDP growth rate in the first place. Even if unobserved, target values of $b^{*}$ and $g$ do play a greater role, their importance should not be overstated if compared with the ability of budget surplus to bring about a decrease in $r_{t}-y_{t}$., which is of uncontestable instrumental flavor in attaining fiscal sustainability.

${ }^{3}$ Both budget surplus and the GDP-adjusted real interest rate have a unit root, or I(1), according to the KPSS test, although ADF and PP tests indicate weak stationarity of $g_{t}$ and $r_{t}-y_{t}$ (results are available on request). All tests imply unit root for $e_{t}$ and $c a_{t}$.
} 
Table 2. The Johansen test for cointegration between $g_{t}, r_{t}-y_{t}, e_{t}$, and $c a_{t}$

\begin{tabular}{|l|c|c|c|c|c|c|c|}
\hline $\begin{array}{c}\text { Number of cointegrating } \\
\text { equations }\end{array}$ & $\begin{array}{c}\text { Trace sta- } \\
\text { tistic }\end{array}$ & $\begin{array}{c}\mathbf{0 . 0 5} \text { Crit- } \\
\text { ical value }\end{array}$ & Prob. & $\begin{array}{c}\text { Max-Eigen } \\
\text { statistic }\end{array}$ & $\begin{array}{c}\mathbf{0 . 0 5} \text { Crit- } \\
\text { ical value }\end{array}$ & Prob. \\
\hline $\mathrm{H}_{0}: r=r_{0}$ & $r=0$ & $64.43^{* * *}$ & 47.85 & 0.00 & $35.78^{* * *}$ & 27.58 & 0.00 \\
\cline { 2 - 8 } & $r=1$ & $28.64^{*}$ & 29.79 & 0.06 & $19.78^{* *}$ & 21.13 & 0.07 \\
\cline { 2 - 8 } & $r=2$ & 8.86 & 15.49 & 0.37 & 8.42 & 12.26 & 0.33 \\
\cline { 2 - 8 } & $r=3$ & 0.43 & 3.84 & 0.50 & 0.44 & 3.84 & 0.50 \\
\hline
\end{tabular}

Note: $* * *, * *$ and $*$ mean rejection of null hypotheses at $1 \%, 5 \%$ and $10 \%$ level.

Source: own elaboration.

\section{ECONOMETRIC METHODOLOGY AND RESULTS}

First of all, we tested whether budget surplus does affect the gap between real interest rate and GDP growth rate as implied by the algorithm by Croce and Juan-Ramon (2003). Compared with more sophisticated indicators of fiscal sustainability, as proposed by Rudin and Smith (1994), Blanchard (1990) or Talvi and Vegh (2000), there are several advantages of simple approaches to the analysis of transforming economies, for instance, there is no need to assess the equilibrium levels of budget surplus. However, government expenditure and revenues that require data for quite a long period of time create difficulties even for industrial economies. In such a context, a recursive character of fiscal sustainability algorithms does compensate for inability to calculate equilibrium values of the budget balance or public debt.

Following the logic of the algorithm by Croce and Juan-Ramon (2003), our statistical model with the time-varying parameters (TVP) in a state space formulation presents as follows:

$$
\begin{gathered}
\Delta\left(r_{t}-y_{t}\right)=a_{0} \text { CRISIS }_{t}+\beta_{1, t} \Delta\left(r_{t-1}-y_{t-1}\right)+\beta_{2, t} \Delta g_{t-4}+\beta_{3, t} \Delta g_{t-6}+ \\
\beta_{4, t} \Delta e_{t-1}+\varepsilon_{t} \\
\beta_{j, t}=\beta_{j, t-1}+\vartheta_{j, t}, \quad j=1,2,3,4
\end{gathered}
$$

where:

CRISIS - a crisis dummy (1 for 2014Q1 to 2016Q4, 0 otherwise);

$\varepsilon_{t}$ and $\vartheta$ - the stochastic factors.

Except $C R I S I S_{t}$, all variables are in the first differences. The lags of a budget balance variable are chosen according to statistical significance of estimated coefficients.

Equations (8) and (9) are the measurement equation and transition equation, respectively. The vector of coefficients $\beta_{\mathrm{t}}$ is formed through a stochastic generating process, with priors $\beta_{0}$. The recursive procedure is used. Besides indicating the magnitude of a particular effect, it is possible to trace whether any significant variation in the estimates of the coefficients occurs. It should be noticed that our estimation procedure is rather in the spirit of the algorithm by Croce and Juan-Ramon (2003), not its strict realisation, as we do not account deliberately for the target debt ratio. Our estimation procedure is reduced to testing whether the budget surplus brings about a decrease in the GDP-adjusted real interest rate, strong enough to keep the public debt ratio below the target ratio so that $\left(\beta_{t}-\lambda_{t}\right)<1$.

Our filtered TVP estimates are reported in Figure 3 for two models, with control of nominal exchange rate and without it (the estimates were obtained with EViews 9.1 programme). Regardless of the specification, there is a strong positive relationship between the budget surplus and the gap between real interest rate and GDP growth rate with six 
lags, representing stable pattern over the last few years. A similar positive relationship between the budget surplus and $r_{t}-y_{t}$ with four lags is largely lost in the period of 20062008 , but estimates of $\beta_{2}$ show a rising trajectory since the beginning of 2010 . Also, it is likely that the weakening of the coefficient on $g_{t-6}$ is complimented with strengthening of the coefficient on $g_{t-4}$, meaning a shorter delay in the budget balance effects upon the gap between real interest rate and GDP growth rate. Anyway, it seems that the causality $\lambda \rightarrow$ $\beta$ is indeed observed in Ukraine, but with a significant lag.
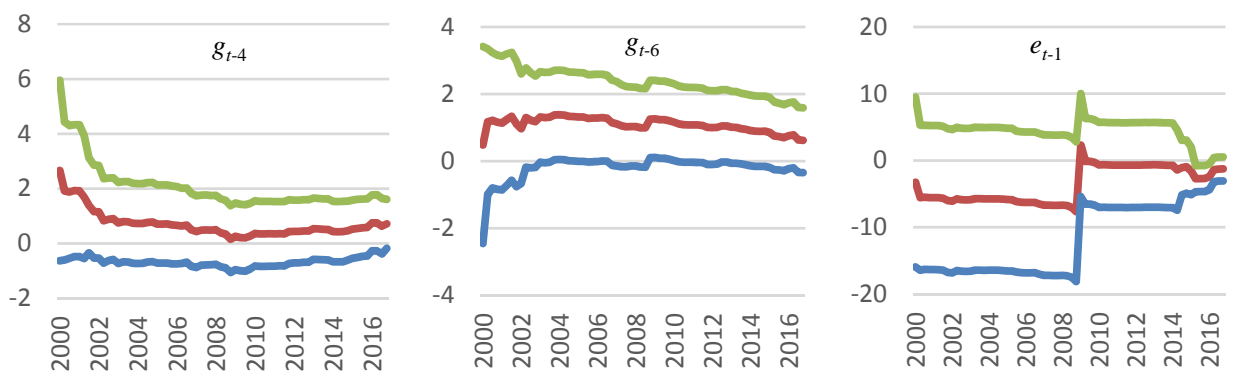

a) control for an exchange rate (Model I)
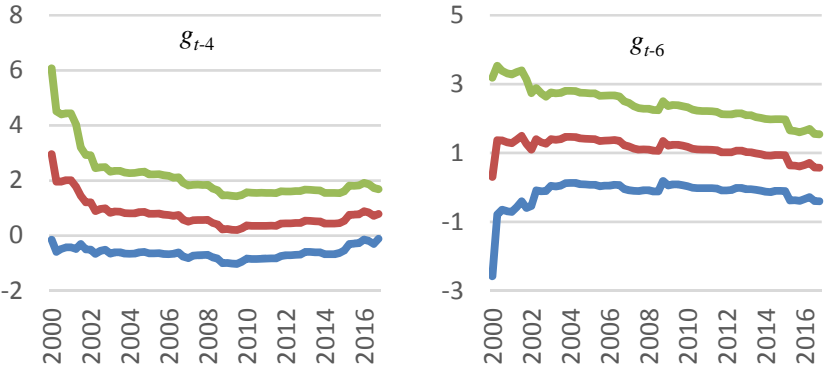

b) no control for an exchange rate (Model II)

Figure 3. The budget surplus effects on the gap between real interest rate and GDP growth rate (the TVP estimates)

Note: the solid line is the point estimate, while the dotted lines represent two-standard error confidence band around this point estimate. Estimates of the coefficients for lagged GDP-adjusted real interest rate are not shown as being insignificant

Source: own elaboration.

Regarding the exchange rate effects on $r_{t}-y_{t}$, there is a clear structural break in 2009 , with a disappearance of rather strong negative impact. The magnitude of negative coefficient on the lagged exchange rate increases slightly since the beginning of 2014 , but it is much smaller when compared with its values over the period of 20022008. As it the effects of crisis dummy upon $r_{t}-y_{t}$ are not detected, it is likely that there are no any specific developments of the 2014-2016 period that are not explained by the budget balance and exchange rate variables.

The sum of the coefficients on $g_{t-4}$ and $g_{t-6}$ is presented in Figure 4 , being an indicator of fiscal sustainability. In addition, estimates are presented for two alternative samples starting in 1998 and 1999, as it is often argued that the Kalman filter estimates could be subject to instability with respect to the choice of the sample. On the other hand, the algorithm by Croce and Juan-Ramon (2003) in its canonical form (Equation (7)) is based upon 
the choice of the steady-state level of public debt $b^{*}$, which is made rather arbitrarily (Chalk \& Hemming, 2000). In such a context, the initial point of the sample could be viewed as a proxy for the country-specific target debt ratio.

5

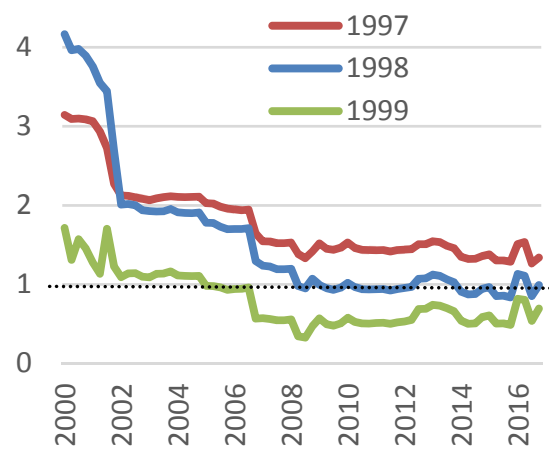

a) control for an exchange rate (Model I)
5

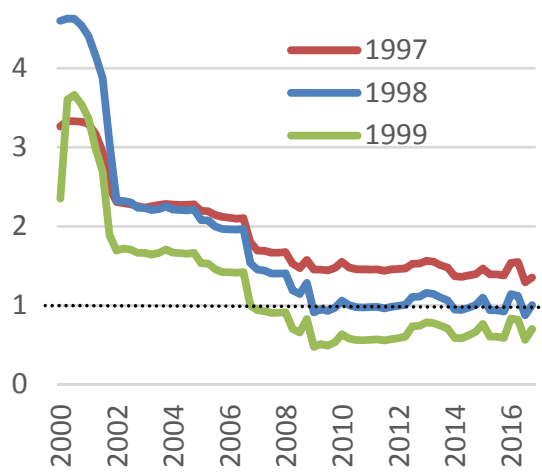

b) no control for an exchange rate (Model II)

Figure 4. The aggregate effect of lagged budget surplus coefficients upon $r_{t}-y_{t}$ Source: own elaboration.

Although there are no significant differences in the pattern of TVP estimates across the two specifications, it is easily recognised that using a more recent starting point of the Kalman filter brings about a much more optimistic view of the fiscal sustainability in Ukraine. If we choose the year 1997 as a starting point for the Kalman filter, the lack of fiscal sustainability is present not only for the pre-crisis period of 2000-2008, but for the post-crisis years as well. On the other hand, estimates for 1999 as a starting year indicate fiscal sustainability since 2009 , which is not a credible outcome assuming tremendous fiscal problems in the following years.

As there is a relative stability of the relationship between $g_{t}$ and $r_{t}-y_{t}$ over the 20062016 period, especially in the specification with $e_{t}$ and the year 1997 as a starting point for the Kalman filter, it is reasonable to apply the VAR methodology as an alternative way of the fiscal sustainability testing that combines both retrospective and prospective features (Tanner \& Samake, 2008). Beginning in some base period, the evolution of public debt is based on either a baseline policy or accumulated shocks. Then simulations of the model allow for using of the 'fan chart' forecasts in order to calculate the average primary surplus required to stabilise public debt at a given time horizon.

Assuming co-integration of $g_{t}, r_{t}-y_{t}, e$, and $c a$, with rank $r(0<r<n)$, all I(1) variables according to the KPSS test, the VAR/VEC model should be used as follows:

$$
A(L) \Delta z_{t}=-\alpha \beta z_{t-1}+\varepsilon_{t}
$$

where:

$A(L)$ - the matrix polynomial of degree $k$;

$\alpha$ and $\beta-n \times r$ matrices of rank $r$;

$z_{t}$ - a vector of endogenous variables $\left(z_{t}=\left(g_{t}, r_{t}-y_{t}, e_{t}, c a_{t}\right)\right)$;

$\varepsilon_{t}-$ a vector of stochastic shocks. 
It is assumed that the budget balance affects the gap between real interest rate and GDP growth rate in the current period, while being independent of the latter. However, a two-way causality between both endogenous variables is assumed for future periods. Both $g_{t}$ and $r_{t}-y_{t}$ affect an exchange rate in the current period, with the changes in the current account balance to follow. The relationship between $g_{t}$ and $r_{t}-y_{t}$ is tested for two specifications, with a nominal exchange rate (local currency per U.S. dollar) as an exogenous variable (Model I) or without it (Model II), and 2000-2008, 2000-2012 and 20002016 data samples. Also, the six-month London-Interbank Offer Rate (LIBOR) and the net foreign direct investment inflows (FDI) are included as independent variables.

The long-run coefficients for the budget surplus effect upon $r_{t}-y_{t}$ are presented in Table 3. Our results indicate the lack of fiscal sustainability regardless of samples and model specifications, as an improvement in the budget balance does not bring about a decrease in the gap between real interest rate and GDP growth rate, being in accordance with the TVP estimates.

Table 3. The long-run coefficients for the budget surplus effect upon $r_{t}-y_{t}$

\begin{tabular}{|c|c|c|}
\hline Sample & Model I (with exchange rate) & Model II (without exchange rate) \\
\hline 2000Q1-2008Q4 & $6.802(3.67)$ & $2.703(0.73)$ \\
\hline 2000Q1-2012Q4 & $5.553(0.71)$ & $2.659(0.70)$ \\
\hline 2000Q1-2016Q4 & $2.506(0.60)$ & $4.901(1.51)$ \\
\hline
\end{tabular}

Note: standard errors in brackets

Source: own elaboration.

The impulse response functions to a one standard deviation shock for short-term relationships are presented in Figure 5. The estimations do not represent serial correlation, while the impulse-response functions are all stable. If we control for an exchange rate, the short-run response of $r_{t}-y_{t}$ to the budget surplus, is very similar for the 2000-2012 and 2000-2016 samples, with the response function revealing a gradual increase in the coefficient on $g_{t}$ to about 5 and 3, respectively. For the 2000-2008 sample, the budget surplus seems to be neutral in respect to $r_{t}-y_{t}$. In the VAR/VEC model without exchange rate, estimates for the coefficient on $g_{t}$ for the 2000-2008 sample reveal the weakest response of $r_{t}-y_{t}$, while it is the strongest for the 20002016 sample. However, the difference between response functions are small enough. In all cases, the value of response function implies lack of fiscal sustainability, which does not conflict with the TVP estimates. Following the budget surplus shock, it is most likely that the magnitude of the response by the gap between real interest rate and GDP growth rate does not signal the fiscal sustainability in Ukraine.

The analysis of the forecast error variance decomposition (FEVD) for the 20002008 sample shows that the budget surplus is responsible for up to $23 \%$ (Model I) and $32 \%$ (Model II) of changes in the gap between real interest rate and GDP growth rate with a horizon of 16 quarters (Table 4). On the other hand, this effect is twice that strong for the shorter sample of 2000-2012, while the fraction of $g_{t}$ in the FEVD of $r_{t}-y_{t}$ is marginal for the 2000-2008 sample (Model I). If not control for the exchange rate (Model II), the fraction of budget surplus as a factor behind changes in $r_{t}-y_{t}$ increases above $60 \%$ for the pre-crisis period of $2000-2008$, with very similar results for the 2000-2012 sample. 
6

4

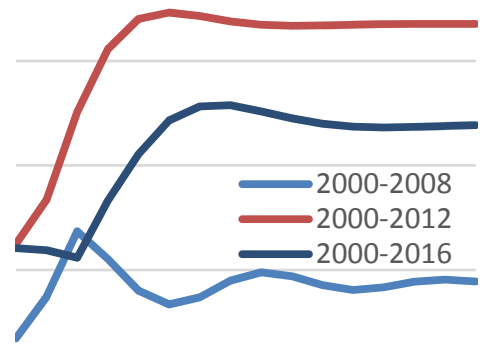

$-2$

$\begin{array}{llllllll}2 & 4 & 6 & 8 & 10 & 12 & 14 & 16\end{array}$

a) control for an exchange rate (Model I)

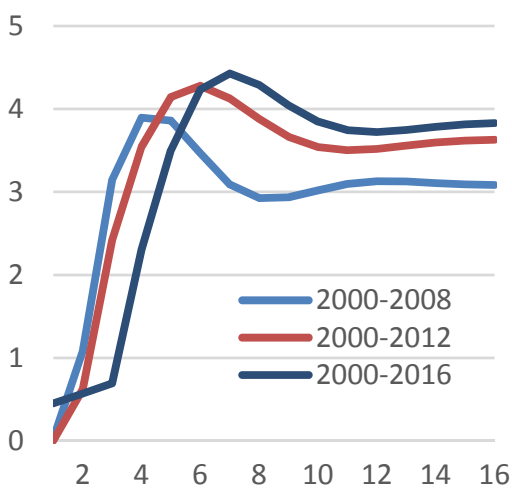

b) no control for an exchange rate (Model II)

Figure 5. The budget surplus effects on the gap between real interest rate and GDP growth rate (the VAR/VEC estimates)

Source: own elaboration.

Table 4. The forecast error variance decomposition of $r_{t}-y_{t}$ responses to innovations in $g_{t}(\%)$

\begin{tabular}{|c|c|c|c|c|c|c|}
\hline \multirow{2}{*}{ Model } & \multirow{2}{*}{ Sample } & \multicolumn{5}{|c|}{ Forecast horizons } \\
\cline { 3 - 7 } & & $\mathbf{1}$ & $\mathbf{4}$ & $\mathbf{8}$ & $\mathbf{1 2}$ & $\mathbf{1 6}$ \\
\hline $\mathrm{I}$ & $2000-2008$ & 4 & 2 & 1 & 1 & 1 \\
\hline & $2000-2012$ & 1 & 20 & 44 & 50 & 53 \\
\hline $\mathrm{II}$ & $2000-2016$ & 1 & 2 & 16 & 21 & 24 \\
\hline & $2000-2008$ & 0 & 31 & 52 & 59 & 63 \\
\hline & $2000-2012$ & 0 & 20 & 41 & 46 & 48 \\
\hline & $2000-2016$ & 1 & 4 & 24 & 29 & 32 \\
\hline
\end{tabular}

Source: own study.

On the whole, our results are in line with majority of empirical studies for the CEE countries which report problems with fiscal sustainability, for example Aristovnik and Bercic (2007), Krejdl (2006), Mihaljek (2009), or rather weak evidence in favour of sustainable fiscal indicators (Krajewski, Mackiewicz, \& Szymańska, 2016; Tronzano, 2017). In order to correct fiscal imbalances, it is necessary to close loopholes in the tax system in the first place or implement necessary expenditure cuts, for example on natural gas subsidies for households. Compared with the CEE countries, fiscal policies in Ukraine should be more restrictive as the GDP growth rate is more volatile and vulnerable to external conditions. Consequently, it is not feasible to rely on high GDP growth as a source of budget balance improvements, similar to the experience of the Czech Republic and Poland in 2016-2017. Also, it is worth noting that excessive reliance on external public debt diminishes the attractiveness of exchange rate depreciation as an instrument of macroeconomic rebalancing, as it was the case in Poland over the 2009-2016 period. Moreover, larger exchange rate misalignments could further complicate the assessment of fiscal sustainability in the presence of significant foreign liabilities. As established by Blanchard and Das (2017), either exchange rates that appear overvalued may still imply a reasonably high probability 
that debt is sustainable at the current exchange rate, or exchange rates that appear undervalued (as in Ukraine) may still come with a reasonably low probability that debt is unsustainable at the current exchange rate.

\section{CONCLUSIONS}

In the article, both the time-varying parameters (TVP) and vector error-correction autoregression (VAR/VEC) models are used in order to test for the fiscal sustainability in Ukraine. Estimation procedures are conducted in accordance with the recursive algorithm derived from the law of motion of the debt-to-GDP ratio developed by Croce and JuanRamon (2003). Compared with alternative approaches, it does not require data for government expenditure and revenues for quite a long period of time. The main conclusion from our study is that Ukraine lacks fiscal sustainability, as indicated by the pattern of relationship between the primary budget surplus and the gap between real interest rate and GDP growth rate. Regardless of the specification, there is a strong positive relationship between the budget surplus and the gap between real interest rate and GDP growth rate with six quarter lags, representing stable pattern over the last few years. If testing for fiscal sustainability, it is important to control for the exchange rate effects, and it is quite natural to assume that it will be a high share of foreign liabilities in the total public debt that aggravates a situation. Assuming an undervaluation of the Ukraine's currency ranging from 80 to $100 \%$ according to different estimates, it is a challenge for future studies to establish the impact of that kind of exchange rate misalignment upon the fiscal sustainability.

Our findings argue in favour of discretionary fiscal policy actions aimed at an increase in the government revenues combined with the public sector expenditure cuts, as current policies do not seem to be sufficient to achieve fiscal sustainability. However, a more detailed study is needed in order to identify most efficient approaches for a decrease in the budget deficit across a detailed 'menu' of expenditure and revenues. On the other hand, any attempts to decrease interest rate and/or stimulate output growth by an expansionary monetary stance are likely to be counterproductive in the presence of substantial public external debt under the risk of exchange rate misalignment.

\section{REFERENCES}

Afonso, A. (2005). Fiscal Sustainability: The Unpleasant European Case. FinanzArchive, 61, 19-44.

Aldama, P., \& Creel, J. (2016). Why Fiscal Regimes Matter for Fiscal Sustainability Analysis: An Application to France. Documents de Travail de l'OFCE, 2016-15.

Aristovnik, A., \& Bercic, B. (2007). Fiscal Sustainability in Selected Transition Countries. MPRA Paper, 122.

Bajo-Rubio, O., Diaz-Roldán, C., \& Esteve, V. (2009). Deficit sustainability and inflation in EMU: An analysis from the Fiscal Theory of the Price Level. European Journal of Political Economy, 25(4), 525-539. https://doi.org/10.1016/j.ejpoleco.2009.04.001

Besancenot, D., Huynh, K., \& Vranceanu, R. (2004). Default on sustainable public debt: illiquidity suspect convicted. Economics Letters, 82(2), 205-211. https://doi.org/10.1016/j.econlet.2003.08.002

Blanchard, O. (1990). Suggestions for a New Set of Fiscal Indicators. OECD Working Paper, 79.

Blanchard, O., \& Das, M. (2017). A New Index of External Debt Sustainability. PIIE Working Paper, 17-13. Washington: Peterson Institute of International Economics. 
Bohn, H. (1995). The Sustainability of Budget Deficits in a Stochastic Economy. Journal of Money, Credit, and Banking, 27(1), 257-271. https://doi.org/10.2307/2077862

Bohn, H. (2007). Are stationarity and cointegration restrictions really necessary for the intertemporal budget constraint?. Journal of Monetary Economics, 54(7), 1837-1847. https://doi.org/10.1016/j.jmoneco.2006.12.012

Bökemeier, B., \& Stoian, A. (2016). Debt Sustainability Issues in the Central and Eastern European Countries. Working Papers in Economics and Management, 07-2016, Bielefeld: Bielefeld University.

Bravo, A., \& Silvestre, A. (2002). Intertemporal sustainability of fiscal policies: some tests for European countries. European Journal of Political Economy, 18(3), 517-528. https://doi.org/10.1016/ S0176-2680(02)00103-9

Chalk, N., \& Hemming, R. (2000). Assessing Fiscal Sustainability in Theory and Practice. IMF Working Paper, WP/00/81.

Ciżkowicz, P., Rzońca, A., \& Trzeciakowski, R. (2015). Membership in the Euro area and fiscal sustainability. Analysis through panel fiscal reaction functions. NBP Working Paper, 203. Warsaw: National Bank of Poland.

Croce, E., \& Juan-Ramon, V. (2003). Assessing Fiscal Sustainability: A Cross-Country Comparison. IMF Working Paper, WP/03/145.

Cruz Rodriguez, A. (2014). Assessing fiscal sustainability in some selected countries. Theoretical and Applied Economics, XXI(6), 7-22.

European Union (2010). EU Sustainability Report-2009. Luxembourg: Office for Official Publications of the European Communities.

Genorio, H. (2005). General Government Debt Sustainability in Slovenia. Prikazi in Analize, XII(2), 57-87.

Giammarioli, N., Nickel, C., Rother, P., \& Vidal, K.-P. (2006). Assessing Fiscal Soundness: Theory and Practice. Banca d'Italia Fiscal Policy Workshop, 637-672.

Green, C., Holmes, M., \& Kowalski, T. (2001). Poland: a successful transition to budget sustainability?. Emerging Markets Review, 2(2), 160-182.

Herzog, D., \& Dausch, L. (2015). Public Debt Sustainability in Europe and Leading Countries. Journal of Empirical Economics, 4(4), 207-215.

Hemming, R., \& Petrie, M. (2000). A Framework for Assessing Fiscal Vulnerability. IMF Working Paper, WP/00/52.

Krajewski, P., Mackiewicz, M., \& Szymańska, A. (2016). Fiscal Sustainability in Central and Eastern European Countries - A Post-Crisis Assessment. Prague Economic Papers, 25(2), 175-188.

Krejdl, A. (2006). Fiscal Sustainability - Definition, Indicators and Assessment of Czech Public Finance Sustainability. CNB Working Paper Series, 3. Prague: Czech National Bank.

Mihaljek, D. (2009). The Global Financial Crisis and Fiscal Policy in Central and Eastern Europe: The 2009 Croatian Budget Odyssey. Financial Theory and Practice, 33(3), 239-272.

Mendoza, E., \& Ostry, J. (2008). International Evidence on Fiscal Solvency: Is Fiscal Policy "Responsible"?. Journal of Monetary Economics, 55(6), 1081-1093. https://doi.org/10.1016/j.jmoneco. 2008.06.003

Paunovic, I. (2005). Public debt sustainability in the northern countries of Latin America. CEPAL Review, 8(7), 95-112.

Rudin, J., \& Smith, G. (1994). Government Deficits: Measuring Sustainability and Solvency. In W.B. Robson \& W.M. Scarth (Eds.), Deficit Reduction: What Pain? (pp. 126-157). Toronto: C. D. Howe Institute. 
Talvi, E., \& Vegh, C. (2000). La sostenibilidad de la politica fiscal: un marco básico. In E. Talvi \& C. Vegh (Eds.), Cymo armar el rompecabezas fiscal?: nuevos indicadores de sostenibilidad (pp. 1-26). Washington, D.C.: Inter-American Development Bank

Tanner, E., \& Samake, I. (2008). Probabilistic Sustainability of Public Debt: A Vector Autoregression Approach for Brazil, Mexico, and Turkey. IMF Staff Papers, 55(1), 149-182.

Tanner, E. (2013). Fiscal Sustainability: A 21st Century Guide for the Perplexed. IMF Working Paper, WP/13/89.

Tóth, C. (2012). Debt Dynamics and Sustainability. Hungarian Statistical Review, 16, 123-149.

Tronzano, M. (2017). Testing Fiscal Sustainability in the Transition Economies of Eastern Europe: The Case of Poland (1999-2015). Economia Internazionale / International Economics, 70(1), 103-132.

Wysocki, M. (2017). Sustainability of Public Debt Stock in Transition Economies in Central and Eastern Europe Countries in Terms of Solvency. Economic Studies, XCII(1), 61-83.

\section{Authors}

The contribution share of authors is equal and amounted to $50 \%$ each of them.

\section{Victor Shevchuk}

Professor at the Cracow University of Technology, main research interests: balance-of-payments adjustment, exchange rate models, fiscal-monetary mix in open economies.

Correspondence to: Dr hab. Viktor Shevchuk, prof. PK, Cracow University of Technology, Faculty of Physics Mathematics and Computer Science, Institute of Economics, Sociology and Philosophy, Warszawska 24, 31-155 Krakow; e-mail: victorshevchuk@netscape.net vshevchuk@pk.edu.pl

\section{Roman Kopych}

Associate Professor at the Ivan Franko National University of Lviv, main research interests: fiscal policy in transformation economies, sustainability of public debt.

Correspondence to: Ass. Prof. Roman Kopych, Ivan Franko National University of Lviv, Department of International Economic Relations, 1, Universytetska Str., 79-005 Lviv, Ukraine; e-mail: kopych_r@bigmir.net

\section{Acknowledgements and Financial Disclosure}

The article came into being within the preparations for the 24th Polish-Slovak-Ukrainian Scientific Seminar titled: Statistical Methods in Socio-Economic Research - Theory and Applications, held on October 11th to 13th, 2017 and organised by the Cracow University of Economics

\section{Copyright and License}

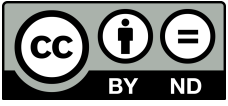

This article is published under the terms of the Creative Commons

Attribution - NoDerivs (CC BY-ND 4.0) License

http://creativecommons.org/licenses/by-nd/4.0/

\section{Published by the Centre for Strategic and International Entrepreneurship - Krakow, Poland}


